Original Research Paper

\title{
Characterization of the Sheep Farming System in the Brazilian Semiarid from the Multivariate Perspective
}

\author{
${ }^{1,4}$ Janaina Kelli Gomes Arandas, ${ }^{2}$ Ângelo Giuseppe Chaves Alves, ${ }^{3}$ Olivardo Facó, \\ ${ }^{3}$ Ernandes Barboza Belchior, ${ }^{3}$ Luciana Shiotsuki and ${ }^{1,5}$ Maria Norma Ribeiro \\ ${ }^{I}$ Department of Animal Science, University Federal Rural de Pernambuco, Recife Brazil \\ ${ }^{2}$ Department of Biology, University Federal Rural de Pernambuco, Recife Brazil \\ ${ }^{3}$ Fazenda Três Lagoas, Embrapa Caprinos e Ovinos, Sobral, Brazil \\ ${ }^{4}$ Fundação de Apoio à Pesquisa do Estado de Pernambuco, FACEPE, Brazi \\ ${ }^{5}$ Conselho Nacional de Desenvolvimento Científico e Tecnológico, CNPq, Brazi
}

Article history

Received: 17-03-2020

Revised: 03-06-2020

Accepted: 01-07-2020

Corresponding Author: Janaina Kelli Gomes Arandas Department of Animal Science, University Federal Rural de Pernambuco, Recife Brazil Email: janaina_arandas@hotmail.com

\begin{abstract}
This study aimed to characterize the purebred Morada Nova sheep and crossbred farming systems in Ceará State, Brazil, through multivariate analysis. The study was carried out in the Morada Nova municipality in Ceará. Thirteen representative Morada Nova pure sheep Breeders (MNB) and 48 crossbreds' breeders of Morada Nova with other breeds (CMN) were interviewed. Was used a questionnaire-based including 12 variables: Breeder Age (BA); Herd Size (HS); Breeding System (BS); feed Supplementation (SUPLE); season feed supplementation (winter or summer); Age at Sexual maturity of Ram (ASR); Ram Discard Age (RDA); Age at Sexual maturity of the Ewe (ASE); Ewe Discard Age (EDA); Commercialization (COM); family participation (FAMP); Main Breeder Activity (MBA). Descriptive statistics and variance analysis were performed, followed by Tukey's test for the comparison of the farming systems of the two studied groups. Variables that characterize the farming systems were subjected to factorial analysis, cluster and discriminant analysis. Based on the factorial analysis, the variables SUPLE, SEASON, ASR, EDA, BA, HS and MBA most significantly contributed to the characterization of farming systems in both studied groups. There was obtained a high level of error classification of breeders to their origin group, due to the handling homogeneity between the studied groups. Multivariate analyses are useful for characterizing the farming system, but the results found can be influenced by the nature or characteristics of the data evaluated.
\end{abstract}

Keywords: Multivariate Analysis, Breeding Practices, Local Breed, Livestock System, Small Ruminants

\section{Introduction}

Sheep were the first animals domesticated by humans and have been playing a crucial role in the beginnings of civilization (Fernandes, 1999). The domestic sheep introduced in Brazil in the colonization are mainly descendants of Portuguese and African breeds (Figueiredo, 1980; Paiva et al., 2005). These animals went through a long process of natural and artificial selection, which promoted the fixation of particular characteristics necessary for the adaptation to local conditions.

Sheep, especially those of local breeds, are important for the subsistence of human populations in developing countries. These breeds have multiple functions and significantly contribute to the income of small-scale farmers in marginal areas as well as noticed in the literature (Beneberu and Jabarin, 2006; Kosgey, 2004; Kosgey and Okeyo, 2007; Thiruvenkadan et al., 2009). They provide high-quality protein due to their excellent ability to transform fodder composed of grasses and legumes into foods with high protein value for human consumption (Gonzaga Neto et al., 2005; Odoi et al., 2000).

The sheep production is an essential component of livestock in the Brazilian semiarid. The Morada Nova breed stands out among the breeds of the Brazilian Northeastern, due to its high adaptive capacity to the 
region. In 1937, it was described by Domingues (1941) during a visit to the National Department of Animal Production in Morada Nova Municipality, in Ceará State. Due to its high adaptive capacity, they are used by smallholders to meat and skin production (Fernandes, 1992). However, despite its social and cultural importance, the Morada Nova breed is in a vulnerable situation (Ribeiro et al., 2014) and indiscriminate crosses with other breeds have contributed to genetic erosion; this is noticeable by the increasing number of crossbred animals over the years.

Sheep production is an economic activity present on all continents, at different climates, soils and vegetation (Silva, 2004). In general, it is performed in extensive systems with low levels of technology (Casale et al., 2008), mainly in small family farms (Costa et al., 2008). However, a knowledge of local farming systems is essential to define sustainable development strategies by local conditions (Castel et al., 2003; Zumbach and Peters, 2000), once it is one of the main steps for breeding program implementation based on the demands and needs of the target community (Mueller et al., 2015).

Studies on the characterization of the farming system generally involve many traits. The individual analysis of each trait is imprecise and provides a partial view of the farming system. On the other hand, multivariate refers to a set of statistical methods that simultaneously analyze multiple traits (Ferraudo, 2005). This statistical procedure has been widely used for the analysis of data related to breeding characterization (Yakubu et al., 2011; Birteeb et al., 2013; Mishra et al., 2017; Arandas et al., 2017). Multivariate procedures could be useful to farming systems characterization, but their use is still rather scarce in this context of the animal production mainly in studies with small ruminant (Usai et al., 2006).

In this context, this study aimed to characterize the farming system of pure Morada Nova sheep and its crossbred progeny in the breed origin place, Ceará State, Brazil through multivariate analysis.

\section{Materials and Methods}

\section{Study Area}

The study was carried out in the municipality of Morada Nova, which is part of the $10^{\text {th }}$ Ceará State Administrative Region. It covers an area of $2,779 \mathrm{~km}^{2}$ and is the $6^{\text {th }}$ municipality of the state, located $152 \mathrm{~km}$ from the capital (Fortaleza city). The headquarters of the municipality is located at $5^{\circ} 6^{\prime} 24^{\prime \prime S}$ and $38^{\circ} 22^{\prime} 21^{\prime \prime} \mathrm{W}$, at an elevation of $89 \mathrm{~m}$ (IBGE, 2014).

Morada Nova is an agricultural and agro-industrial development center with a population of 61,903 inhabitants, according to the IBGE census 2014. The climate is semiarid, with an average annual rainfall of $742.5 \mathrm{~mm}$. The dry period lasts for more than eight months and a drought period is characterized by a dry season longer than one year (IBGE, 2014). The rainy season is short and irregular and occurs from February to April.

Goat and sheep farming occur in 10 and $16 \%$, respectively, of the rural establishments in Ceará State (Farias et al., 2014). In Morada Nova, sheep and goats predominate, followed by cattle and pigs (Campos, 2003). According to local livestock research (IBGE, 2014), the Morada Nova sheep herd is among the ten most abundant in the state, with 43,011 heads, mainly containing Morada Nova animals crossbred with other breeds, commonly used in the regions Dorper and Santa Inês.

\section{Sampling and Data Collection}

Data were obtained through semi-structured interviews with the 13 remaining breeders of Morada Nova sheep (MNB) and 48 breeders of crossbred herds, resulting from the crossing of Morada Nova animals with other breeds commonly used in the region, with the predominance of Santa Inês breed (CMN). For semistructured interviews (Albuquerque et al., 2010), a questionnaire was used; the questions addressed the social and, demographic profiles of the breeders and the breeding system in terms of food, sanitary conditions and reproductive management to obtain the information (traits): Breeder Age (BA); Herd Size (HS); Breed System (BS); Feed supplementation (SUPPLE ); feed supplementation Season - winter or summer (SEASON); Age at Sexual maturity of Ram (ASR ); Ram Discard Age (RDA); Age at Sexual maturity of the Ewe (ASE); Ewe Discard Age (EDA); Commercialization (COM); Family Participation (FAMP); Main Breeder Activity (MBA). The interviews were conducted locally with questionnaires completed at the ' 'respondent's place of residence, by a single the interviewer, to avoid misinterpretation. All interviewed breeders signed informed consent. Privacy rights were ensured.

\section{Statistical Analyses}

Social and demographic aspects and the breeding system mentioned in item 2.2. were submitted to frequency distribution analyses. The age of introduction and discard of ram and ewe to the breeding season were submitted to variance analysis and the mean ages taken from both groups were compared by Tukey's test $(5 \%$ significance).

Data were submitted to factorial analysis, based on principal components, to summarise the original variable set (breeder social profile; food, health and reproductive management), in some independent factors and identify variables that most contributed to the farming system characterization. We used varimax orthogonal rotation, which has a more significant potential to interpret factors. The Joliffe criterion was used to choose factors (Jolliffe, 1972; 1973), whose sum of eigenvalues should explain, at least, $70 \%$ of the total variation. 
Cluster analysis was used to identify homogenous 'breeder's groups, using the Ward method. Also, discriminant analysis was performed to identify traits with higher factor load and classify individuals into their origin groups. Multivariate analyses were performed with the support of FACTOR, CLUSTER and DISCRIM procedures of the software package Statistical Analysis System (SAS, 1999).

\section{Results and discussion}

\section{Social and Demographic Profiles of the Studied Groups}

The general characteristics of the social and demographic profiles of the two studied groups are shown in Table 1. The reduced number of breeders interviewed in each group denotes the current breed demography. The number of purebred breeders is decreasing with a consequent increase of crossbred herds. Most of breeders interviewed in groups were of male gender, with culture inherited from interaction of Portuguese settler culture with that of the Indians. This population has its own culture (sertaneja), marked by its dedication to their land and by specific characteristics of their way of life, family organization and power structuring (Andrade, 1963; Folch, 2011).

Table 1: General characteristics of the surveyed groups

\begin{tabular}{|c|c|c|c|c|}
\hline \multirow[b]{3}{*}{ Variables } & \multicolumn{4}{|c|}{ Groups of breeders } \\
\hline & \multicolumn{2}{|c|}{ MNB } & \multicolumn{2}{|c|}{$\mathrm{CMN}$} \\
\hline & $\mathrm{N}$ & $\%$ & $\mathrm{~N}$ & $\%$ \\
\hline \multicolumn{5}{|l|}{ Sex } \\
\hline Male & 13 & 100 & 43 & 89.58 \\
\hline Female & - & - & 5 & 10.42 \\
\hline \multicolumn{5}{|l|}{ Age (years) } \\
\hline $20-40$ & - & - & 8 & 16.67 \\
\hline $41-50$ & 4 & 30.77 & 13 & 27.08 \\
\hline $51-70$ & 7 & 53.85 & 25 & 52.08 \\
\hline$>70$ & 2 & 15.38 & 2 & 4.17 \\
\hline \multicolumn{5}{|l|}{ Defined as } \\
\hline Farmer & 4 & 30.76 & 26 & 54.17 \\
\hline Breeder & 2 & 15.39 & 8 & 16.67 \\
\hline Farmer and breeder & 5 & 38.46 & 14 & 29.16 \\
\hline Other functions & 2 & 15.39 & - & - \\
\hline \multicolumn{5}{|l|}{ Main income source } \\
\hline Agriculture & 1 & 7.69 & 8 & 16.67 \\
\hline Bovine farming & 5 & 38.47 & 20 & 41.67 \\
\hline Sheep & 1 & 7.69 & 5 & 10.41 \\
\hline Poultry farming & 1 & 7.69 & - & - \\
\hline Goat breeding & - & - & 1 & 2.08 \\
\hline * Mixed system & 4 & 30.77 & 12 & 25.00 \\
\hline Others & 1 & 7.69 & 2 & 4.17 \\
\hline
\end{tabular}

*Mixed system = Livestock (goats, sheep, cattle, pigs) and agriculture. $*$ MNB $=$ Morada Nova breeders. $* \mathrm{CMN}=$ Crossbred Morada Nova breeders
The predominance of breeders of the male gender is typical in animal husbandry in the northeastern Brazilian. In general, rural women are essential economic agents who contribute to household incomes and the development of their community in several ways. They occupy a subordinate position and their work generally appears as "help", even though they work as hard as men or perform the same activities (Brumer, 2004). Studies also indicate that the "head of the family" is not always the primary decision-maker and that gender determines in part how resource allocation decisions are made on a farm (Handa, 1994; Doss, 1996; 2001; McPeak and Doss, 2006).

The predominance of breeders of the male gender responsible for animal care is also a feature found in other parts of the world, especially in developing countries. For example, on the African continent, Urgessa et al. (2012), characterizing sheep and goat farming systems in Ethiopia also found a predominance of breeders of males' gender in livestock production as well as Umunna et al. (2014) in Nigeria.

The highest proportion of breeders in both investigated groups was 51 to 70 years old. The rural exodus can explain the small number of young breeders in this area, which is common in Brazil and other developing countries (Ayantunde et al., 2007; Nascimento, 2013). This action seriously threatens the future of livestock breeding (Vinholi and Martins, 2012).

Although agriculture was not the main activity of most interviewees, $38.46 \%$ of the MNB group defined themselves as farmers and breeders. In the crossbred breeders (CMN) group, over half $(54.17 \%)$ defined themselves as farmers. This self-denomination makes them feel socially included and be recognized by their farmer's condition, their ways of working as well as for possession and control of necessary production means (Wanderley, 2015).

In the study area, goat and sheep farming predominated (Campos, 2003). However, both studied groups reported bovine farming as their primary activity and source of income, with emphasis on milk cattle. Cattle farming has been performed in the Morada Nova municipality since the 18th century, mainly on family farms; according to some breeder reports, the gains from cattle farming are used for the payment of general expenses. Sheep is regarded as a way of "savings," which can be used sporadically.

The state of Ceará covers the most significant part of the semiarid territory and $89 \%$ of the rural establishments are family-based, with diversified farming activities (Campos, 2004; Farias et al., 2014).

Mixed systems, that is, farming systems based on livestock (goat, sheep, cattle and pig production) and agriculture, were most often used by breeders and are considered the primary source of income for $30.77 \%$ of 
Morada Nova breeders. According to the interviewed breeders, this diversification in the farming system allows the use of resources in a balanced way, mainly in terms of resource availability (animals and agriculture), access to the market, or the capacity to generate income. Farias et al. (2014) verified the adoption of a diversified system (animal and grain yield) when evaluating family breeders in the Ceará semiarid region, considering as essential component for farming system resilience as a way of maintaining family autonomy in the studied territory.

In many tropical developing countries, animal farming systems are very diversified, mainly due to agroecological development (Wurzinger et al., 2006; Gizaw et al., 2010). In this context, small ruminants are also crucial as a diversification strategy aimed at reducing market and climatic risks and optimizing the use of available resources (Valdivia and Nolan, 1996). The diversification of the farming systems has been a trend in the South America region, as verified by Salamanca et al. (2015) in southern Peru south and by Yáñez and Marchan (2012) in Chile. The diversification is also prevalent in countries of the African continent and includes small plots with mixed farming systems (agriculture and livestock) (Kosgey et al., 2006).

However, only $38 \%$ of Morada Nova breeders can count on family member participation to take care of their herds. The small portion of family members involved in breeding is worrisome for the conservation and maintenance of the Morada Nova breed, due to most breeders are already relatively old (Fig. 1) and rural exodus as yet discussed.

\section{Breeding of the Studied Herds}

Table 2 shows the general characteristics of the two studied groups. Most pure herds contained between 31 and 200 animals, whereas crossbred herds were generally lower (30 to 100 animals) but with several crossbred herds significantly higher than that of pure herds, indicating breed replacement and, consequently, genetic erosion. This situation was confirmed by Ribeiro et al. (2014) when evaluating the status of Morada Nova sheep breed. These authors observed genetic material loss, with an effective number $\left(\mathrm{N}_{\mathrm{e}}\right)$ less than 50, the minimum value recommended by the FAO (1998). This situation is common and ultimately leads to a loss of genetic material and the disappearance of the resilient local breeds.

In this present survey, it was observed a prevalence of animals raised free in the native grasslands (> 80\%) in both groups of evaluated breeders. In northeastern Brazil, the rearing of small ruminants has historically been practiced extensively, with little or no technical assistance (Nunes, 2008; Santos, 2014; Souza, 2004). Feeding was based on native grassland, without the use of technologies; mating was uncontrolled and there was no record keeping. This management system has been practiced for several years, as reported by Muniz et al. (2011).

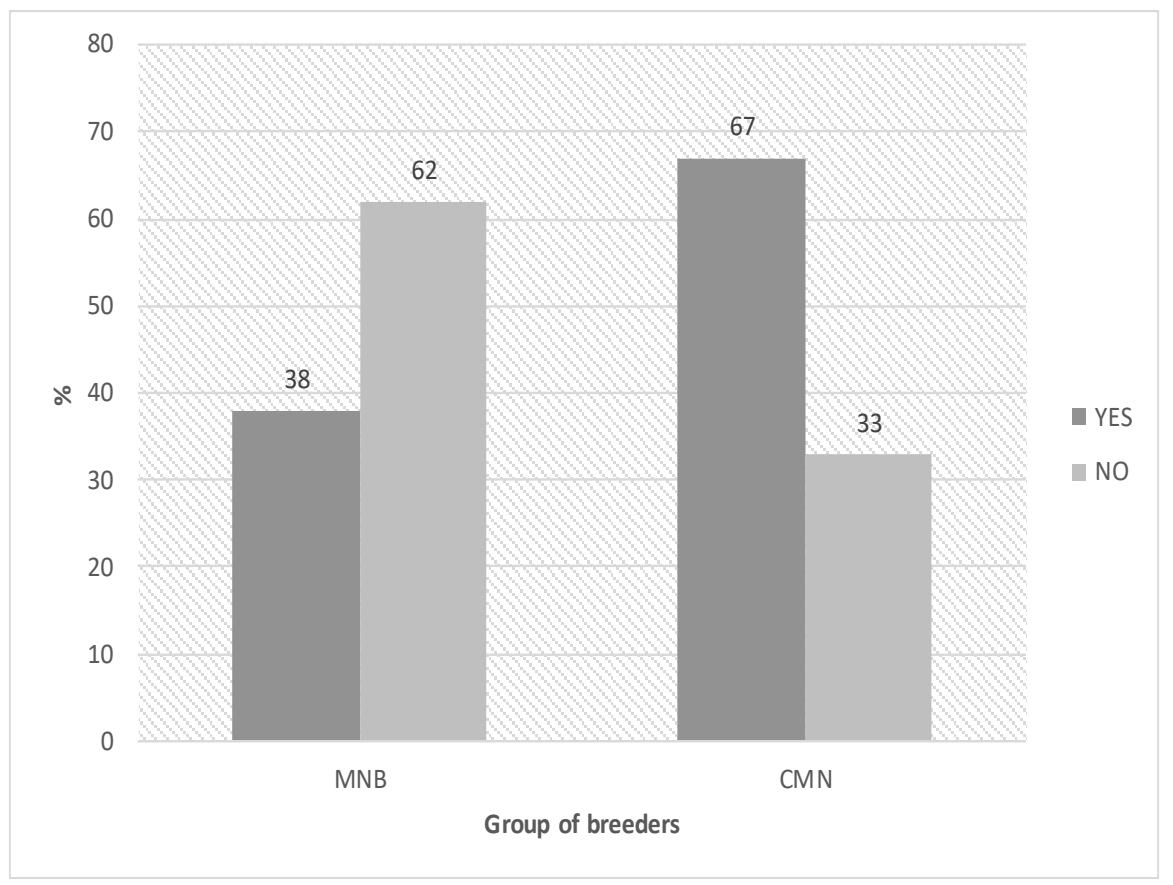

Fig. 1: Family participation in the farming system $(\%)$ according to the studied groups. $\mathrm{MNB}=$ Morada Nova breeders. $\mathrm{CMN}=$ Crossbred Morada Nova breeders 
Table 2: General characteristics of Morada Nova and crossbreed production systems

\begin{tabular}{|c|c|c|c|c|}
\hline \multirow[b]{3}{*}{ Variables } & \multicolumn{4}{|c|}{ Groups of breeders } \\
\hline & \multicolumn{2}{|c|}{ MNB* } & \multicolumn{2}{|c|}{$\mathrm{CMN} *$} \\
\hline & $\mathrm{N}$ & $\%$ & $\mathrm{~N}$ & $\%$ \\
\hline \multicolumn{5}{|l|}{ Herd size (animals) } \\
\hline$<30$ & 1 & 7.69 & 15 & 31.25 \\
\hline 31 to 60 & 4 & 30.77 & 16 & 33.33 \\
\hline 61 to 100 & 3 & 23.08 & 11 & 22.92 \\
\hline $101-200$ & 3 & 23.08 & 4 & 8.33 \\
\hline $201-300$ & 1 & 7.69 & 1 & 2.08 \\
\hline$>300$ & 1 & 7.69 & 1 & 2.08 \\
\hline \multicolumn{5}{|l|}{ Management system } \\
\hline Extensive & 11 & 84.62 & 44 & 91.67 \\
\hline Semi-extensive & 2 & 15.38 & 4 & 8.33 \\
\hline \multicolumn{5}{|l|}{ Nutritional management } \\
\hline Food supplementation & 12 & 92.30 & 44 & 91.67 \\
\hline Without supplementation & 1 & 7.69 & 4 & 8.33 \\
\hline \multicolumn{5}{|l|}{ Supplementation period } \\
\hline Drought & 12 & 100.00 & 44 & 100.00 \\
\hline \multicolumn{5}{|l|}{ Sanitary management } \\
\hline Vermifugation & 13 & 100.00 & 48 & 100.00 \\
\hline \multicolumn{5}{|l|}{ Purpose of production } \\
\hline Live animals for the meat market & 6 & 46.15 & 31 & 64.58 \\
\hline Reproduction & 1 & 7.69 & 1 & 2.08 \\
\hline Meat market and reproduction & 3 & 23.08 & 7 & 14.58 \\
\hline Meat market and breeding animals & 3 & 23.09 & 2 & 4.17 \\
\hline Self-consumption & - & - & 7 & 14.58 \\
\hline
\end{tabular}

$* \mathrm{MNB}=$ Morada Nova breeders. $* \mathrm{CMN}=$ Crossbred Morada Nova breeders

Local breeds, such as the Morada Nova breed, are often characterized by multiple functionalities, making them perfectly suited to the prevailing rearing system in the region. Nowadays, crossbreeding of Morada Nova sheep are common in the region. Generally, crossbred animals have less adaptive attributes, which are required to fulfill multiple roles (Drucker et al., 2001). In local farming systems with limited resources, local breeds may be more promising than crossed and pure exotic breeds (Ayalew et al., 2003; Tibbo et al., 2008). Besides, crosses represent a severe threat to the local genetic heritage.

\section{Nutritional Management of the Herds}

Although the extensive breeding system was prevalent, $92.30 \%$ of the Morada Nova breeders and $91.67 \%$ of the crossbreed breeders offered supplementation during the dry season, when food resources are dramatically reduced (Table 2). Generally, sorghum and corn silage were offered; this approach is typical for goats and sheep and prevents malnutrition (Costa et al., 2008). In dry areas in developing countries, feed supplementation is commonly practiced (Silva, 2002; Urgessa et al., 2012).

The primary feed source in the studied area is the Caatinga vegetation, which is an essential and major food source in the dry northeastern regions during the dry season. During the rainy season, feed is abundant, while in the dry season, forage availability and quality are reduced (Silva et al., 2010). Campos (2003), studying sheep and goat rearing systems in Ceará state, also found that native pasture grass was the primary feed source throughout the year. This approach is common in most poor regions in the world, as reported by Gebretsadik and Anal (2013) for northern Ethiopian sheep farms.

\section{Sanitary and Reproductive Profiles of the Herds}

Sanitary management in extensive systems is generally confined to herd deworming. All investigated breeders vermifuge their animals up to four times throughout the year (Table 2). The deworming is the most used sanitary practice in the region, albeit with questionable results (Alencar et al., 2008).

Table 3 shows the averages standard deviation (months) of the age of introduction and discard of ram and ewe for breeding in the herds of the two studied groups. We found no significant differences in ram and ewe introduction and discard ages among the studied groups; however, the ewes remained in the herds for longer (Table 3).

In general, rams entered breeding at 10 or 11 months and were replaced at about 24 months. The less time the animal is kept in the herd, the higher the genetic gain. However, this limited time of stay contributes to a loss 
of origin genes and represents a severe threat to the breed genetic diversity. Therefore, in conservation programs, the generation intervals should be increased, and more considerable attention should be given to mating management to control consanguinity and its unfavorable effects.

The breeders try to prevent inbreeding mates, but it is difficult once, another usually replaces breeding animals from the same herd. The use of animals from outside the herd would facilitate the genic flow and contribute to increased intra-breed diversity. The rams are mainly responsible for the genetic improvement of the herd and are, therefore, of great importance for the efficiency of the farming system (Azevêdo et al., 2008).

In our research, only $30.77 \%$ of Morada Nova breeders participate or have already participated in the genetic improvement program (Fig. 2) (Facó et al., 2008). The low participation can be explained by the fact that breeding programs for goats and sheep have often failed because of obstacles such as the lack of zootechnical records and breeder participation (Shiotsuki and Facó, 2013).

All breeders of crossbred animals did not participate in the breeding program (Fig. 2) since the animals are mostly produced for slaughtering. In general, only purebred breeders participated in the breeding program, because their main objective is the genetic selection.

Purebred Morada Nova ewes (MNB) are introduced in the herds for reproduction at the age of 9 months and are discarded at about 72 months of age, which is much earlier than in the crossbred group (CMN). This practice may contribute to lower generation interval and loss of genetic material. In conservation programs, breeding animals should be kept for longer to favor the maintenance of the genes of origin (Bodó, 1992).

\section{Productive Profiles and Commercialization of Herds}

Although the Morada Nova breed is highly appreciated for both reproduction and sold as live animals for the meat market, only about $23.09 \%$ of the breeders sold their animals for breeding (Table 2). Most of the breeders send their animals for slaughter, (46.15\%) for MNB and (64.58\%) for CMN.

Table 3: Mean age and standard deviation (months) of introduction and discard of ram and ewe to breeding in the two studied groups

\begin{tabular}{lll}
\hline & \multicolumn{2}{l}{ Breeder group } \\
& ---------------- \\
Ages (months) & MNB $^{*}$ & CMN $^{*}$ \\
\hline Age of ram introduction & $11 \pm 2.93^{\mathrm{a}}$ & $10 \pm 2.51^{\mathrm{a}}$ \\
Age of ram discard & $24 \pm 0.52^{\mathrm{a}}$ & $24 \pm 0.87^{\mathrm{a}}$ \\
Age of ewe introduction & $9 \pm 1.91^{\mathrm{a}}$ & $9 \pm 2.55^{\mathrm{a}}$ \\
Age of ewe discard & $72 \pm 1.70^{\mathrm{a}}$ & $60 \pm 1.09^{\mathrm{b}}$ \\
\hline
\end{tabular}

Values with similar lowercase letters within row do not differ significantly from each other by Tukey's test at $5 \%$ probability level. $*$ MNB $=$ Morada Nova breeders. $* \mathrm{CMN}=$ Crossbred Morada Nova breeders

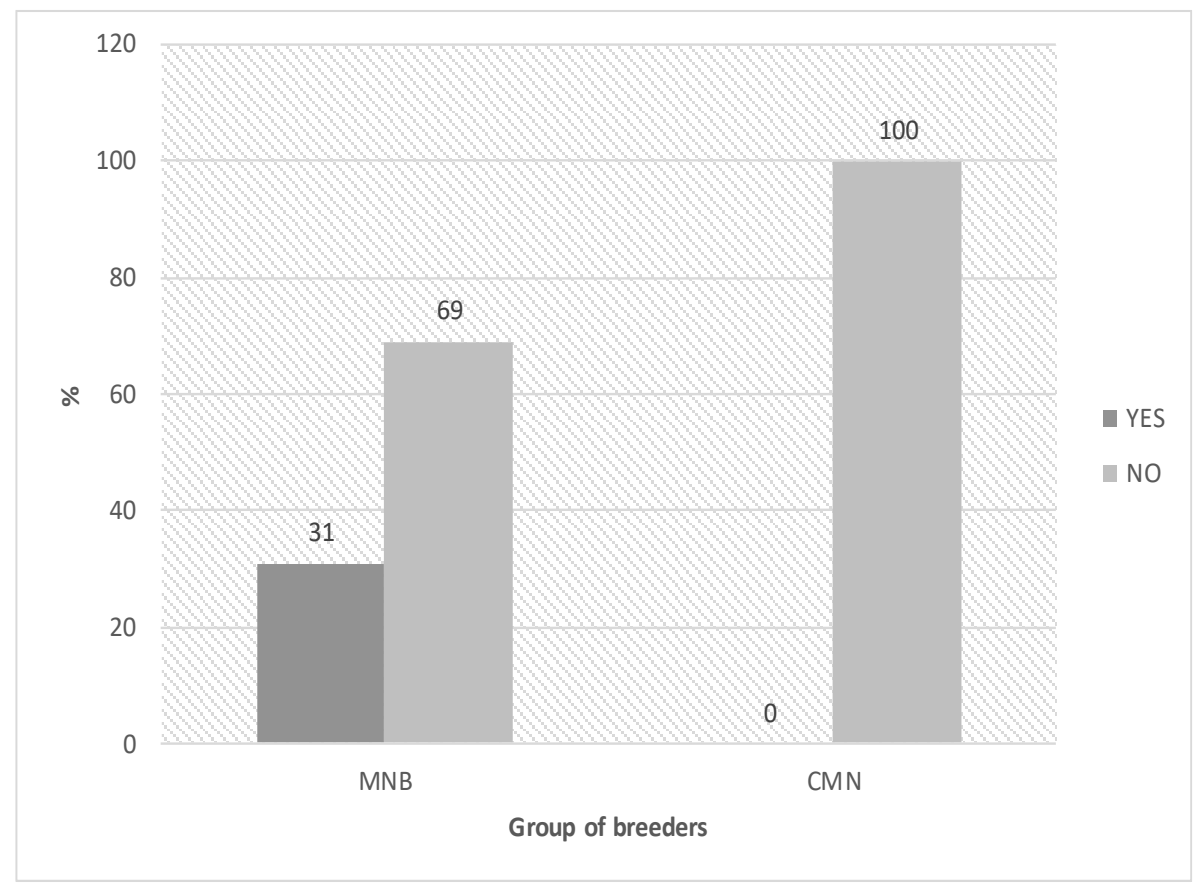

Fig. 2: Percentages of breeders participating in genetic breeding programs. $\mathrm{MNB}=$ Breeders of Morada Nova breed. $\mathrm{CMN}=$ Breeders of Crossbred Morada Nova breed 
The skin of Morada Nova sheep, although of high quality, is not efficiently used (Jacinto et al., 2004) due to an insufficient infrastructure for commercialization. In general, according to Santos et al. (2008), the sheep slaughtering in Brazil considers the carcass as the primary marketing unit. However, various by-products, such as the skin, represent a potential source of income.

In the group that raises crossbreed animals (CMN), the activity was solely performed for slaughtering and sale $(64.58 \%)$. The current world consumption of sheep meat stands at about $2.5 \mathrm{~kg}$ per person annually out of annual meat consumption of $41.6 \mathrm{~kg}$ per person (Morris, 2017). In Brazil, there has been a considerable increase in the sheepmeat market in recent years, mainly because of the increased demand for sheep meat in urban areas (Ziguer et al., 2011). However, the productive chain of the sheep industry in Brazil is high informality, due to precarious control. This situation favors illegal slaughter and the consequent sale of informal carcasses, which represents a barrier that must be overcome to determine the real value of sheepmeat consumption (Sorio and Rasi, 2010). According to Bankuti and Souza Filho (2006), the informal production of sheep meat can be reduced by joint actions of the health surveillance system and the inspection system. In Brazil, the health surveillance system is limited to the survey of the general hygienic conditions of retail establishments and of the quality of the product offered for sale but neglecting the origin of the product (Sorio and Rasi, 2010).

\section{Multivariate Analyses}

Table 4 shows a summary of the factorial analysis for the 12 variables used to characterize the farming system. Out of the 12 linear combinations generated, the first six explained $75 \%$ of the variation (Table 4), allowing a $50 \%$ reduction of the sample space. Ibidhi et al. (2018), characterizing the sheep farming system in Tunisia through a multivariate approach, also found six components that together explained $82 \%$ of the total variation. Differences may occur due to local conditions, quantity and type of traits used to explain the phenomena and variation retained by each one.

The commonality obtained in the present study ranged from 0.443 to 0.921 (Table 5). This parameter indicates the extent to which variables explain the cumulative variation of the factor (Morrison, 1976). Variables with commonality less than $50 \%$ have little explanatory power.

Table 4: Factors, eigenvalues, Percentage of Explained Variance (\%PEV) and Percentage of the Cumulative Variance explained $(\% \mathrm{PCV})$ of the studied traits of farming system

\begin{tabular}{llll}
\hline Factor & Eigenvalues & $\%$ PEV & $\%$ FCV \\
\hline 1 & 2.45076253 & 0.2042 & 0.2042 \\
2 & 1.77618391 & 0.1480 & 0.3522 \\
3 & 1.40247008 & 0,1169 & 0.4691 \\
4 & 1.23938355 & 0.1033 & 0.5724 \\
5 & 1.17433094 & 0.0979 & 0.6703 \\
6 & 1.00230293 & 0.0835 & 0.7538 \\
\hline
\end{tabular}

Table 5: Factor loads for the variables used to characterize the purebred Morada Nova sheep and crossbreed farming system

\begin{tabular}{lrrrrrrr}
\hline Variables & Factor 1 & Factor 2 & Factor 3 & Factor 4 & \multicolumn{1}{c}{ Factor 5 } & \multicolumn{1}{l}{ Factor 6 } & C \\
\hline BA & -0.26831 & -0.02882 & $\mathbf{0 . 6 3 6 2 2}$ & 0.13446 & -0.34742 & 0.29595 & 0.70397227 \\
HS & -0.30130 & 0.44833 & 0.29916 & -0.22030 & $\mathbf{0 . 5 0 5 7 4}$ & 0.20671 & 0.72831495 \\
BS & -0.20678 & 0.55603 & 0.08079 & -0.56429 & 0.02159 & 0.22783 & 0.72924721 \\
SUPPLE & $\mathbf{0 . 9 4 7 2 2}$ & 0.03767 & 0.01808 & -0.08347 & 0.12281 & 0.01312 & $\mathbf{0 . 9 2 1 1 9 8 8 2}$ \\
SEASON & $\mathbf{0 . 9 4 7 2 2}$ & 0.03767 & 0.01808 & -0.08347 & 0.12281 & 0.01312 & $\mathbf{0 . 9 2 1 1 9 8 8 2}$ \\
ASR & 0.04834 & $\mathbf{0 . 8 1 1 7 4}$ & -0.06427 & 0.19617 & -0.00961 & -0.15934 & 0.72934663 \\
RDA & -0.08662 & 0.24207 & -0.57422 & 0.34081 & 0.43822 & 0.09513 & 0.71307142 \\
ASE & 0.39045 & 0.43400 & 0.03349 & 0.40369 & $\mathbf{- 0 . 5 3 7 6 8}$ & 0.13488 & 0.81219440 \\
EDA & -0.23870 & -0.05551 & 0.29339 & $\mathbf{0 . 7 0 6 9 0}$ & 0.36001 & 0.00980 & 0.77555275 \\
COM & 0.34946 & -0.30821 & 0.56365 & -0.02229 & 0.38378 & -0.11110 & 0.69489485 \\
FAMP & 0.25128 & 0.47157 & 0.36717 & 0.11877 & 0.06177 & -0.07080 & 0.44326653 \\
MBA & 0.21504 & -0.18981 & 0.16562 & 0.09241 & 0.07268 & $\mathbf{0 . 8 6 5 8 3}$ & 0.87317530 \\
\%PEV $*$ & 20.42 & 14.80 & 11.69 & 10.33 & 9.79 & 8.35 & \\
\hline
\end{tabular}

(\%PEV* = Percentage of Explained Variance; C = Commonality; Breeder Age (BA); Herd Size (HS); Breed System (BS); Feed Supplementation (SUPPLE); feed supplementation Season - winter or Summer (SEASON); Age at Sexual maturity of Ram (ASR); Ram Discard Age (RDA); Age at Sexual maturity of the Ewe (ASE); Ewe Discard Age (EDA); Commercialization (COM); Family Participation (FAMP); Main Breeder Activity (MBA). 
Table 6: Percentage of breeders classified in each group according to the evaluated traits

\begin{tabular}{llc}
\hline Breeder group & CMN $(\%)$ & MNB $(\%)$ \\
\hline MNB & 89.58 & 10.42 \\
CMN & 69.23 & 30.77 \\
Total $(\mathrm{N})$ & 52.00 & 9.00 \\
\hline
\end{tabular}

* MNB $=$ Morada Nova Breeders. $* \mathrm{CMN}=$ Crossbred Morada Nova breeders

The Supplementation (SUPPLE) and SEASON traits showed the most significant commonality, mainly because they were variables of higher load in the first factor. In general, the most variables showed commonalities above the 0.5 , suggested by Hair Júnior et al. (2009), a good fit of the model. The high commonality of a variable group is an indication that they are linearly correlated and, therefore, should be included in factorial analysis. So, we named the first factor of the "nutritional factor." Food supplementation is a strategy used to reach the nutritional requirements of the animals and to maintain a proper animal development; supplements can be given at any time of the year, a variable commonly inserted in studies on the characterization of animal production systems (Silva et al., 2009; Batista, 2015). In the Brazilian semiarid region, supplementation is generally performed in the dry season due to lower food availability.

The feed is one of the most critical parts of the animal production systems. Hence, the feeding strategies adopted influences several features, among them, the composition of the lamb meat and, consequently, its sensorial characteristics. The quality and quantity of food resources available to animals depend mainly on climatic and seasonal aspects (Priolo et al., 2001; Schreurs et al., 2008; Montossi et al., 2013).

The age of ram for breeding in the herd was the most loaded variable in the second factor, justifying its inclusion in characterization studies. The ram can reach sexual maturity as early as at six months of age (Nunes et al., 1997), the importance of the trait in the second factor, reflects the reproductive management system that varies from herd to herd.

The breeder age had the highest load in the third factor. Social variables are essential to be included in this kind of study once the age of breeder can indicate current trends and prospects for animal breeding. Studies indicate that as older as of the head of the family, higher the probability to the family to keep small ruminants. The younger is more likely to volunteer and work part-time in the neighbouring periurban area while the older one remains on the farm. The age of the breeder is a variable that influences the farming systems once the number of young breeders has been decreasing over time due to lack of incentives and to public policies to attract young people to rural areas (Dossa et al., 2008).

However, public policies to keep young people involved in livestock is essential to ensure the continuity of family farms, which are responsible for a significant percentage of food produced in Brazil and other developing countries (FAO, 2007).

The age of the breeder was also an essential variable in studies on dairy farms (Lopes Junior et al., 2012), indicating that this variable is of fundamental importance within any family production chain.

The age of ewe discard was of minor importance when compared to that of rams. However, it should not be neglected and in this study, it showed the most significant load in the fourth factor that contributed $10 \%$ of the total variation. Other variables of minor importance, although they should also receive considerable attention, were herd size and the breeding ewe age. These are variables with more weight on the fifth factor. The ewe produces offspring and, consequently, increase the number of animals in the herd; they are, therefore, essential variables in the same factor. The ewe is fertile before it has completed its body development. Therefore, early mating should be avoided because they can compromise future ewe development (Derivaux, 1980; Hafez, 1988; Dukes, 1996).

In this study, the leading breeder activity was in the sixth-factor group, which allows verifying the context and level of importance of sheep on the whole sheep production chain. Although the breeder activity is associated with a factor that adds less variability (8\%), its importance should not be disregarded, since it is a determining characteristic of future animal production.

Figure 3 shows the dendrogram obtained by the Ward method with two clusters formed. The first cluster was subdivided into subgroups with distances near zero, indicating homogeneity of characteristics in the two studied groups.

The second cluster was formed by only one isolated breeder that was influenced by the herd size, which is outside the observed general reality, representing an outlier. Most crossbreed animal breeders (CMN) were tightly grouped, indicating the social and demographic profiles as well as similar sanitary conditions, food supply and reproductive management. On the contrary, Morada Nova breeders were spread among various subgroups, indicating that this group presents a homogeneity concerning the social and demographic aspects and the feeding of the animals, in the sanitary conditions and the reproductive management with the group of crossbreeds of the breed. 


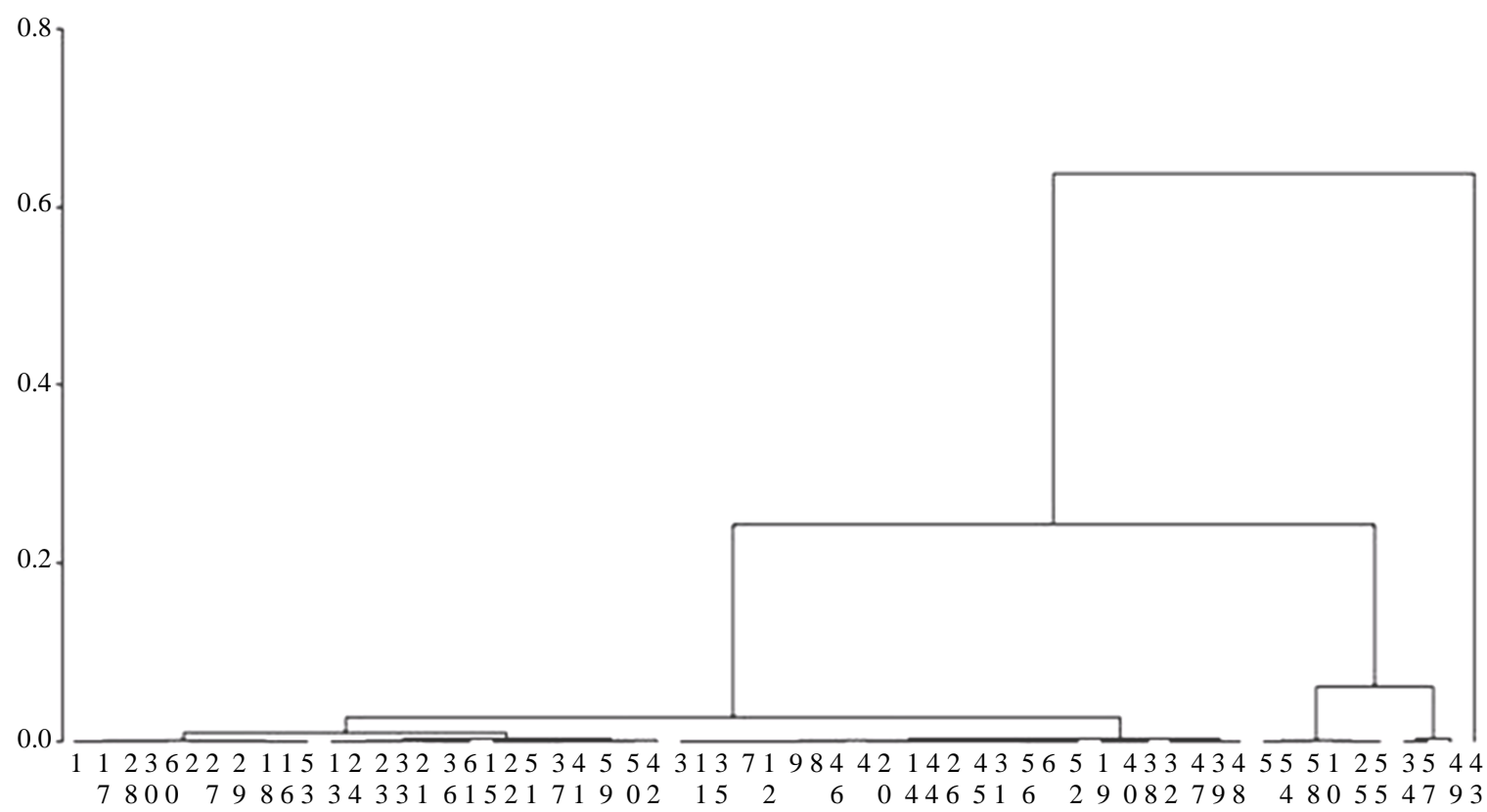

Fig. 3: Dendrogram obtained by the Ward method to characterize the farming system (1-48 CMN breeders, 49-61 = MNB breeders

The discriminant analysis not allowed to discriminate the two groups of breeders studied due to the homogeneity between the groups of breeders. It was observed that $69.23 \%$ of MNB group breeders were classified to origin group and only $10.42 \%$ of the CMN were classified in their origin group (Table 6). These results are in agreement with the cluster analysis, in which some of the CMN group breeders were scattered among the formed subgroups (Fig. 3). Arandas et al. (2017) evaluating selection criteria and the selection objective adopted by these two groups observed the same trend.

Morada Nova sheep can easily be managed and are highly adapted to semiarid areas, with low feed requirements. They play essential historical and social roles in semiarid areas of Brazil.

\section{Conclusion}

Multivariate analyses are useful for characterizing the farming system, but the results found can be influenced by the nature or characteristics of the data evaluated.

The supplementation (SUPPLE) and Season of Supplementation (SEASON) are crucial in studies of the farming system since these traits have a higher commonality and highest factor load in the first factor. These traits together with 'Breeder's Age (BA), the Ewe Discard Age (EDA), Herd Size (HS), Age at Sexual maturity of the Ewe (ASE) and Main Breeder Activity (MBA) were the most important to characterize the farming system in the two studied groups.

The factor analysis was useful to identify a set of six latent constructs to characterize the farming system and the discriminant analysis does not allow to discriminate the two groups of breeders studied, due to the handling homogeneity between the studied groups.

\section{Acknowledgment}

The breeders of Morada Nova sheep

\section{Funding Information}

To the Empresa Brasileira de Pesquisa Agropecuária (EMBRAPA) for the funding of the research project and to the Fundação de Amparo à Ciência e Tecnologia de Pernambuco (FACEPE) for the granting of the research grant.

\section{Author's Contributions}

Janaina Kelli Gomes Arandas: Responsible for the development of research and preparation of the scientific article that is derived from the doctoral thesis of the first author.

Ângelo Giuseppe Chaves Alves: Contribution to the development of research and scientific review of the content of the article.

Olivardo Facó: Contribution to the development of research and scientific review of the content of the article.

Ernandes Barboza Belchior: Contribution to the development of research.

Luciana Shiotsuki: Contribution to the development of research. 
Maria Norma Ribeiro: Project coordinator, contribution to the development of research and scientific review of the content of the article

\section{Ethics}

The research was carried out following the ethical norms established for research with humans, as a signature of the Free and Informed Consent Form, which is an essential and fundamental document of the protocol and the research with ethics.

\section{References}

Alencar, S.P., A. Mota and M.C.O.C. Coelho, 2008. Socioeconomic profile of goat breeding in the backlands of Pernambuco. Proceedings of the Brazilian Congress of Veterinary Medicine, (CVM' 08), Conbravet, Gramado.

Albuquerque, U.P., R.F.P. Lucena and N.L. Alencar, 2010. Métodos e Técnicas Para Coleta de Dados Etnobiológicos. In: Métodos e Técnicas na Pesquisa Etnobiológica e Etnoecológica, Albuquerque, U.P., R.F.P. Lucena and L.V.F.C. Cunha (Eds.), Recife, Núcleo Publicações em Ecologia e Etnobotânica Aplicada (NUPEEA), pp: 39-64.

Andrade, M.C., 1963. Earth and Man in the North. Ed. Brasiliense, São Paulo.

Arandas, J.K.G., N.M.V. Da Silva, R.B. Nascimento, E.C.P. Filho and L.H.A. Brasil et al., 2017. Multivariate analysis as a tool for phenotypic characterization of an endangered breed. J. Applied Anim. Res., 45: 152-158.

DOI: $10.1080 / 09712119.2015 .1125353$

Ayalew, W., B. Rischkowsky, J.M. King and E. Bruns, 2003. Crossbreds did not generate more net benefits than indigenous goats in Ethiopian smallholdings. Agric. Sys., 76: 1137-1156.

DOI: $10.1016 / \mathrm{S} 0308-521 \mathrm{X}(02) 00033-1$

Ayantunde, A.A., M. Kango, P. Hiernaux and H. Udo, 2007. Herders' Perceptions of ruminant livestock breeds and breeding management in southwestern Nigeria. Hum. Ecol., 28: 109-129.

DOI: $10.1007 /$ S10745-006-9049-6

Azevêdo, D.M.M.R., R. Martins Filho and A.A. Alves, 2008. Comportamento sexual de ovinos e caprinos machos: Uma revisão. Pubvet, 140: 2-6.

Batista, R.N.D., 2015. Supplementation of lambs in tropical grassland in the phase of termination. Master's Dissertation, Federal Technological University of Paraná.

Bankuti, F.I and H.M.A. Souza Filho, 2006, Informalidade em Sistemas Agroindustriais: Os Casos dos Sistemas da Carne Bovina e do Leite. In: Agronegócios: Gestão e Inovação, Zuin, L.F.S. and T.R. Queiroz (Orgs.) Saraiva, São Paulo, pp: 59-87.
Beneberu, T. and A.S. Jabarin, 2006. Sheep price patterns and factors affecting price variations in the highland markets of North Shewa, Ethiopian. Jordan J. Biol. Sci., 2: 65-78.

Birteeb, P.T., S.O. Peters, A. Yakubu, M.A. Adeleke and M.O. Ozoje, 2013. Multivariate characterization of the phenotypic traits of Djallonke and Sahel sheep in Northern Ghana. Tropical Anim. Health Product., 45: 267-274. DOI: 10.1186/s40064-016-1669-8

Bodó, I., 1992. Monitoring Animal Genetic Resources and Criteria for Priority Order of Endangered Breeds. In: The Management of Global Animal Genetic Resources, Rome, Italy, pp: 91-107.

Brumer, A., 2004. Gender and agriculture the situation of women in agriculture in the Rio Grande do Sul. Rev. Est. Fem., 12: 205-227. DOI: 10.1590/S0104-026X2004000100011

Campos, C.K., 2004. Local productive arrangements the case of goat-sheep farming in the municipalities of Quixadá and Quixeramobim. Fortaleza. Federal University of Ceará.

Campos, R.T., 2003. Typology of ovine and caprine producers in the state of Ceará. R. Bras. Econ., 34: 85-112. DOI: 10.5433/1679-0359.2017v38n4p2163

Casale, D.S., P. Ortensi and A. Piccinin, 2008. Um modelo de instalação para a criação de ovinos em semiconfinamento. Rev. Cient. Elet. Med. Vet., 10: 1-6.

Castel, J.M., Y. Mena, M. Delgado-Pertnez, J. Camuñez and J.C. Balsuto et al., 2003. Characterization of Semi-extensive goat production systems in southern Spain. Small Rumin. Res., 47: 133-143. DOI: 10.1016/S0921-4488(02)00250-X

Costa, R.G., C.C. Almeida, P.E. Filho, E.V. Holanda Junior and N.M. Santos, 2008. Characterization of the goat and sheep production system in the semiarid region of Paraíba State, Brazil. Arch Zootec, 57: $195-205$. DOI: $10.5433 / 1679-0359.2017 v 38 n 4 p 2163$

Derivaux, J., 1980. Reprodução dos animais domésticos. Acribia, Zaragoza, Espanha.

Domingues, O., 1941. Carneiro deslanado de Morada Nova. Boletim Sociedade Brasileira Agronomia, 41: 122-122.

Doss, C., 1996. Testing among models of intrahousehold resource allocation. World Dev., 24: 1597-1609. DOI: $10.1016 / 0305-750 \mathrm{X}(96) 00063-0$

Doss, C., 2001. Is risk fully pooled within the household: Evidence from Ghana. Econ. Dev. Cultural Change, 50: 101-130. DOI: 10.1086/340009

Dossa, L.H., B. Rischkowsky, R. Birner and C. Wollny, 2008. Socioeconomic determinants of keeping goats and sheep by rural people in southern Benin. Agric. Hum. Values, 25: 581-592. DOI: $10.1007 / \mathrm{s} 10460-008-9138-9$ 
Drucker, A.G., V. Gomez and S. Anderson, 2001. The economic valuation of farm animal genetic resources- a survey of available methods. Ecol. Econ., 36: 1-18. DOI: $10.1016 / \mathrm{S} 0921-8009(00) 00242-1$

Dukes, H.J., 1996. Domestic animals' phylum gia. Guanabara Koogan, Rio de Janeiro.

Facó, O., S.R. Paiva, L. Alves, R. Lôbo and L. Villela, 2008. Raça Morada Nova - origem, características e perspectivas. Embrapa caprinos. Sobral.

Farias, J., M. Ali and A.R. de Lima, 2014. Análise socioeconômica de produtores familiares de caprinos e ovinos na região semi-árida do Ceará, Brazil. Arch Zootec, 63: 13-24. DOI: 10.4321/S0004-05922014000100002

Fernandes, A.A.O., 1992. Genetic and phenotypic parameter estimates for growth, survival and reproductive traits in Morada Nova hair sheep. PhD Thesis, Oklahoma State University.

Fernandes, F.M.N.A., 1999. Ovinocultura no Contexto Agropecuário Paulista. In: Simpósio Paulista de Ovinocultura, Botucatu.

Ferraudo, A.S., 2005. Técnicas de Análise Multivariada.

Figueiredo, E.A.P., 1980. Morada Nova of Brazil. In: Prolific Tropical Sheep. Mason, I. (Ed.), FAO, Rome, pp: 53-58.

FAO, 1998. Secondary guidelines for the development of national animal genetic resources management plans. Management of small populations at risk. Food and Agriculture Organization of the United Nations.

FAO, 2007. The state of the world's animal genetic resources for food and agriculture - in brief. Rome.

Folch, L.T., 2011. O cancioneiro peninsular e o romanceiro nordestino em Ariano Suassuna. Marrare.

Gebretsadik, Z. and A. Anal, 2013. Indigenous sheep breeds of North Ethiopia- characterization of their phenotype and major production system. Trop Anim. Health Pro., 46: 341-347.

DOI: $10.1007 / \mathrm{s} 11250-013-0494-0$

Gizaw, S., H. Komen and J.A.M. van Arendonk, 2010. Participatory definition of breeding objectives and selection indexes for sheep breeding in traditional systems. Livest. Sci., 128: 67-74.

DOI: 10.1016/j.livsci.2009.10.016

Gonzaga Neto, S., A.G. Silva Sobrinho, K.T. Resende, N.M.B.L. Zeola and A.M.A. Silva et al., 2005. Body composition and nutritional requirements of protein and energy for lambs Morada Nova. R. Bras. Zoot., 34: 2446-2456.

DOI: $10.1590 /$ S1516-35982005000700033

Handa, S., 1994. Gender, headship and intrahousehold resource allocation. World Dev., 22: 1535-1547. DOI: $10.1016 / 0305-750 X(94) 90036-1$
Hafez, E.S.E., 1988. Reprodução animal. Acribia, Zaragoza, Espanha.

Hair Júnior, J.F., R.L. Tatham, R.E. Anderson and W.C. Black, 2009. Análise Multivariada de Dados. 6th Edn., Bookman, Porto Alegre.

IBGE, 2014. Morada Nova/Ceará - dados gerais. Instituto de Pesquisas e Estratégia Econômica do Ceará (IPECE), Perfil Municipal Básico Morada Nova.

Ibidhi, R., A. Frija, M. Jaouad and H. Ben Salem, 2018. Typology analysis of sheep production, feeding systems and farmer's strategies for livestock watering in Tunisia. Small Ruminant Res., 160: 44-53.

Jacinto, M.A.C., A.G. Silva Sobrinho and R.G. Costa, 2004. Características anatômicas-estruturais da pele de ovinos (Ovis aries L.) liberadas e afrouxadas, relacionadas ao aspecto físico-mecânico do couro. R. Bras. Zoot., 4: 1001-1008.

DOI: $10.1590 / \mathrm{S} 1516-35982004000400020$

Jolliffe, I.T., 1972. Discarding variables in the main component analysis. I. Artificial data. Applied Stat., 21: 160-173. DOI: $10.2307 / 2346488$

Jolliffe, I.T., 1973. Discarding variables in the main component analysis. II. Real date. Applied Stat., 21: 21-31. DOI: $10.2307 / 2346300$

Kosgey, I.S., 2004. Breeding objectives and breeding strategies for small ruminants in the tropics. Ph.D. Thesis, Wageningen University and Research Center.

Kosgey, I.S., R.L. Baker, H.M.J. Udo and J.A.M. van Arendonk, 2006. Successes and failures of small ruminant breeding programs in the tropics- a review. Small Rumin. Res., 61: 13-28.

DOI: 10.1016/j.smallrumres.2005.01.003

Kosgey, I.S. and A.M. Okeyo, 2007. Genetic improvement of small ruminants in low-input, smallholder production systems- Technical and infrastructural issues. Small Rumin. Res., 70: 76-88. DOI: 10.1016/j.smallrumres.2007.01.007

Lopes Junior, J., C. Ramos, G.T.D. Santos, P.A. Grande and J.C. Damasceno et al., 2012. Análise das práticas de produtores em sistemas de produção leiteira e seus resultados na produção e qualidade do leite. Semin: Ciênc. Agrár., 3: 1199-1208. DOI: $10.5433 / 1679-0359.2012 v 33 n 3 p 1199$

Mishra, A.K., V. Vohra, K.N. Raja and S. Singh, 2017. Principal component analysis of biometric traits to explain body conformation in Kajali sheep of Punjab, India. Indian J. Anim. Sci., 87: 93-98.

Morrison, D.F., 1976. Multivariate Statistical Methods. 1st Edn., McGraw-Hill Company, New York.

Morris, S., 2017. Overview of Sheep Production Systems. In: Advances in Sheep Welfare, Ferguson, D., C. Lee and A. Fisher (Eds.), Woodhead Publishing, pp: 19-33. 
Montossi, F., M. Font-i-Furnols, M. del Campo, R. San Julián and G. Brito, 2013. SañudoSustainable sheep production and consumer preference trends: Compatibilities, contradictions and unresolved dilemmas. Meat Sci., 95: 772-789.

Muniz, M., T. Santos, F. Neto, S. Queiroz and O. Facó et al., 2011. Desempenho produtivo e reprodutivo de ovinos da raça Morada Nova no Semiárido do Ceará. Proceedings of the 6th Northeastern Animal Production Congress, (APC' 11), Mossoró.

Mueller, J.P., B. Rischkowsky, A. Haile, J. Philipsson and O. Mwai et al., 2015. Community-based livestock breeding programs - essentials and examples. J. Anim. Breed. Genet., 132: 155-168. DOI: $10.1111 /$ jbg. 12136

McPeak, J. and C. Doss, 2006. Are household production decisions cooperative? Evidence on migration and milk sales from northern Kenya. Am. J. Agric. Econom., 88: 525-541. DOI: $10.1111 / \mathrm{j} .1467-8276.2006 .00877 . x$

Nascimento, R.B., 2013. Etnozootecnologia da Raça Moxotó, Impacto dos cruzamentos e Predadores Naturais na Conservação de Raça. Recife. PhD Thesis, Rural Federal University of Pernambuco.

Nunes, J.F., A.L.T. Ciriaco and U. Suassuna, 1997. Produção e reprodução de caprinos e ovinos. 1st Edn., Graph LCR, Fortaleza, pp: 199.

Nunes, S.A., 2008. O setor produtivo de caprinos e ovinos.

Odoi, A., J.M. Gathuma, C.K. Gachuiri, A.O. Omore and T. Gitau et al., 2000. Constraints to sheep and goat production in smallholder mixed farms in Kenya's central highlands. Proceedings of the 9th International Symposium on Veterinary Epidemiology and Economics, (VEE' 00), Kenya.

Paiva, S.R., V.C. Silve River, F.D.A. Paiva, C. McManus and AA. Egypt et al., 2005. Origin of the main locally adapted sheep breeds of Brazil: The RFLP-PCR molecular analysis. Arch. Zootec., 54: 395-399.

Priolo, A., D. Micol and J. Agabriel, 2001. Effects of grass-feeding systems on ruminant meat color and flavour. A review. Anim. Res., 50: 185-200.

Ribeiro, M.N., J.K.G. Arandas, E. Filho and R. da Silva, 2014. Demografia e grau de risco de extinção de ovinos Morada Nova. Rev. Zootecnia Trop., 32: 309-313.

Usai, M.G., S. Casu, G. Molle, M. Decandia and S. Ligios et al., 2006. Using cluster analysis to characterize the goat farming system in Sardinia. Livestock Sci., 104: 63-76.

DOI: 10.1016/j.livsci.2006.03.013

Salamanca, I., A. Catachura, J. Sánchez, M.C.S. Fioravanti and J.R.B. Sereno, 2015. Ovinocultura en el litoral sur de Perú. AICA, 6: 42-48.
Santos, E.M., 2014. Economic analysis of sheep production in genetic selection systems and sale of lambs for slaughter. PhD Thesis, Federal University of Sergipe.

Santos, N.M., R.G. Costa, M.S. Madruga, A.N. Medeiros and C.L.C. Albuquerque et al., 2008. Constitution and composition chemistry of the precooked goat like Buchada produced in the state of Paraíba, Brazil. Braz. Arch. Biol. Technol., 51: 793-798. DOI: 10.1590/S1516-89132008000400017

SAS, 1999. SAS/STAT User's guide. Version 8. v.2. Cary - SAS Institute.

Shiotsuki, L. and O. Facó, 2013. Center for Participatory Genetic Improvement of Morada Nova Sheep. In: Latin American Congress of Specialists on Small Ruminants and South American Camelids, Campo Grande, Brasil.

Silva, F.F., J.F. Sá, A.R. Schio, L.C.V. Ítavo and R.G.M. Silva, 2009. Grassland supplementation availability and quality $\mathrm{x}$ levels of supplementation x performance. R. Bras. Zoot., 38: 371-389. DOI: $10.1590 / \mathrm{S} 1516-35982009001300037$

Silva, N.V., R.G. Costa and C. Freitas, 2010. Alimentação de ovinos em regiões semi-áridas do Brasil. Acta Vet. Bras., 4: 233-241.

Silva, R., 2004. Criação de ovinos no Paraná no contexto nacional e mundial - breve diagnóstico situacional. Curitiba, Secretário de Estado da Agricultura e Abastecimento -SEAB.

Silva, R.R., 2002. O agronegócio Brasileiro de Carne Caprina e Ovina. 1st Edn., Do autor, Salvador, pp: 111.

Souza, R.L., 2004. Agricultura familiar e pluriatividade no semi-árido baiano. Bahia Análises Dados, 4: 921-930.

Sorio, A. and L. Rasi, 2010. Ovinocultura e abate clandestino: um problema fiscal ou uma solução de mercado? Rev. Pol. Agr., 19: 71-83.

Schreurs, N.M., G.A. Lane, M.H. Tavendale, T.N. Barry and W.C. McNabb, 2008. Pastoral flavour in meat products from ruminants fed fresh forages and its amelioration by forage condensed tannins. Anim. Feed Sci. Technol., 146: 193-221.

Thiruvenkadan, A.K., K. Karunanithi and M. Murugan, 2009. A comparative study on the performance of crossbred and purebred Mecheri sheep raised under dryland farming conditions. S Afr. J. Anim. Sci., 39: 121-125. DOI: 10.4314/sajas.v39i1.61325

Tibbo, M., K. Aragaw, J. Philipsson and B. Malmfors, 2008. A field trial of production and financial consequences of helminthosis control in sheep production in Ethiopia. Prev. Vet. Med., 84: 152-160. DOI: 10.1016/j.prevetmed.2007.12.011 
Urgessa, D., B. Duguma, S. Demeke and T. Tolamariam, 2012. Sheep and goat production systems in Ilu Abba Bora zone of Oromia Regional State, EthiopiaFeeding and management strategies. Glob. Vet., 9: 421-429. DOI: 10.5829/idosi.gv.2012.9.4.64162

Umunna, M.O., O. Olafadehan and A.A. Arowona, 2014. Small ruminant production and management systems urban area of Southern Guinea Savanna of Nigeria. Int. J. Agri. Crop Sci., 20: 2321-1571.

Valdivia, C. and M.F. Nolan, 1996. Sociological and economic analysis of small ruminant production systems. Annual Report 95-96, University of Missouri, Columbia and Kenya.

Vinholi, A.C. and P. Martins, 2012. Agricultura urbana e êxodo rural. Rev. Bras. Ciências Soc., 43: 66-79.

Wanderley, M., 2015. O campesinato brasileiro - uma história de resistência. Rev. Econ. Soc. Rural, 52: 25-44. DOI: 10.1590/S0103-20032014000600002

Yáñez, O.R. and S.B. Marchan, 2012. Fundamentos de la producción ovina en la Región de La Araucanía. Temuco. Instituto de Investigaciones Agropecuarias (INIA), Centro Regional Carillanca.
Yakubu, A., A. Salako and A.R. Abdullah, 2011. Varimax rotated principal component factor analysis of the zoometrical traits of Uda sheep. Arch. Zootecnia, 60: 26-37.

DOI: $10.4321 /$ S0004-05922011000300069

Ziguer, E.A., S.R. Tonieto, L.F.M. Pfeifer and R.F. Bermudas, 2011. Economic results of the production of lambs in confinement using soybean hulls associated with four sources of non- protein nitrogen. R. Bras. Zootec., 9: 2058-2065.

DOI: $10.1590 / \mathrm{S} 1516-35982011000900030$

Zumbach, B. and K.J. Peters, 2000. Sustainable breeding methods for smallholder dairy production under unfavorable conditions in the tropics. Deutscher Tropentag. International Agricultural Research, A Contribution to Crisis Prevention.

Wurzinger, M., D. Ndumu, R. Baumung, A. Drucker and A.M. Okeyo et al., 2006. Comparison of production systems and selection criteria of Ankole cattle by breeders in Burundi, Rwanda, Tanzania and Uganda. Trop. Anim. Health Prod., 38: 571-581. DOI: $10.1007 / \mathrm{s} 11250-006-4426-0$ 